\title{
Assessing bank performance measurement in islamic banking industry
}

\author{
Mokhamad Ikhsan Ramdhoni ${ }^{{ }^{*}}$ \\ ${ }^{1}$ Applied Master of Islamic Banking and Finance, Politeknik Negeri Bandung, Indonesia
}

\begin{abstract}
The Indonesian Islamic banking industry, attaining the age of more than 25 years tend to adopt conventional approach to measure its bank performance. Although this method could well inform the performance of the bank financial, this measurement fails to inform both the characteristics of Islamic banking. This study is designed to evaluate three Islamic bank performance measurements: Sharia Maqashid Index, Sharia Conformity and Profitability (SCnP), and CAMELS. Sharia Maqashid Index approach has three variables: educating individual, establishing justice, and public interest. SCnP approach has two variables: Sharia conformity and profitability. While CAMELS approach has five variables: Capital, Asset Quality, Management, Earning, and Liquidity. This study uses data from Islamic Commercial Banks registered on Bank Indonesia from 2012-2016. The data analytical technique is quantitative method using descriptive approach. The results of the study using Sharia Maqashid Index reveal that there is a difference in Islamic Commercial Banks performance. The used of SCnP reveals that none of Islamic Commercial Banks on upper right quadrant. The used of CAMELS reveals that all of Islamic Commercial Banks in Indonesia have Fairly Healthy predicate. These findings suggest that, to provide a comprehensive picture of its performance, the Islamic banks need to adopt both Sharia-based as well as financial based measurement.
\end{abstract}

\section{Introduction}

Currently, the world is entering the era of Industrial Revolution 4.0. This also applies to the banking industry where they are competing to utilize technology to provide excellent service to its customers. This is in line with Senge et al. [1] which states the current challenge is to develop sustainable businesses that are compatible with current economic realities. The financial services sector was an early adopter of key technologies associated with business transformation and it is currently one of the most intensive users of information and communication technologies [2] .

Indonesia's Islamic banking is over 25 years old, but in its age of more than a quarter century it has not had its own performance measurement tools and is still adopting conventional measuring instruments and limited only to financial ratio measurement. The

\footnotetext{
*Corresponding author: ikhsanramdhoni@gmail.com
} 
use of conventional measuring instruments as the only measure of performance in Islamic banks is considered less suitable.

First, scholars [3] state that Islamic banks and conventional banks are characteristically difficult to distinguish. Secondly, several studies have shown that the measurement of performance of Islamic banks with conventional banks is not the same, since the views of core functions and operational characteristics are clearly different [4]. Thirdly, most Islamic banks rely on financial benchmarks to measure their performance results, therefore, many stakeholders cannot clearly see the difference between Islamic and conventional banking. Furthermore, by using conventional benchmarks to measure the performance of Islamic banking there is a discrepancy between conventional banking performance indicators and the broader objectives of Islamic banking. [5]

This is confirmed by researchers [6] which states that the characteristic difference between Islamic banking and conventional banking is something very basic. So the characteristics of services produced will be different, and evaluation of both types of banking will also be different [7]. Therefore, efforts are needed to develop performance measurement tools that will complement the financial objectives of Islamic banking [5]. The development of measuring instruments for performance of Islamic banks is needed to answer one of the research results that the Islamic finance industry is fast growing and innovating but slow in establishing its credibility [8].

In fact, research related to measuring instruments that have been aligned with the characteristics of Islamic banking has been done. Past researchers have attempted to improve performance measurements to align with the characteristics and objectives of Islamic banking [5] with the Sharia Maqashid Index approach, and research with the Sharia Conformity and Profitability (SCnP) method [9]. The results show that the model can be a strategic alternative approach that can illustrate how well the performance of Islamic banking is more universal and can be implemented in the form of a comprehensive policy strategy [10]. The difference of this study with previous studies is in this study the author use several approaches in assessing the performance of Islamic banking. Considering one of the functions of banking is as financial intermediary, the bank is required to always maintain the level of business performance and business health level in order to gain the trust of stakeholders [7]. On the other hand, scholars [10] maintain that because Islamic banks have different characteristics from conventional banks in both concept and practice, Islamic banking should consider performance that not only focus on financial ratios, but also pay attention to Non-financial ratio.

Based on the above background, this study is intended to assess three models of bank performance measurement, namely the measurement of Islamic banking performance using Sharia Maqashid Index model, Sharia Conformity and Profitability model as well as CAMELS model. Such a study is important to assist the Islamic banking industry to evaluate their business performance and subsequently developing appropriate competitive strategy.

\section{Literature review}

In the highly competitive business environment, as as in Islamic bank industry, having a high performance is imperative [11]. Performance appraisal is a management tool for knowing how far the company's objectives have been achieved, evaluating business performance, managers, divisions and individuals within the company, as well as for predicting future company expectations [12]. The information used as a performance measurement or assessment tool is grouped into two categories namely financial performance and Non-financial information [13]. The performance of a bank can be 
identified by using a measuring tool known as CAMELS (Capital, Asset Quality, Management, Earning, Liquidity, and Sensitivity of market risk) analysis. Bank health measurement and rating model through CAMELS analysis has been determined by Bank Indonesia [14]. Non-financial information can increase confidence in the quality management supervision process. A comprehensive performance measurement technique developed by several organizations and companies is a balanced scorecard which includes four measured aspects: financial perspective, customer satisfaction, internal process efficiency, and learning and growth [13].

Mohammed [5] uses a method to define the concept of Maqashid Sharia into a measuring instrument for measuring the performance of Islamic banking. This method describes the Concept $(\mathrm{C})$ into observable behavior and is called Dimension (D). The dimension is then translated into several measurable behaviors called Elements (E). This measurement of performance that have been developed from the framework of Maqashid Sharia and then weighted so that the concept can be used to measure the performance of Islamic banking by weighting each Objective (O) and Element (E) [5].

In the Sharia Conformity and Profitability ( $\mathrm{SCnP}$ ) model there is a merger between profitability indicators to assess conventional financial performance with an index of conformity to sharia values to assess the socio-economic obligations of Islamic banks. The sharia compliance variable consists of the ratio of sharia investment, sharia income, and profit sharing ratio. While the profitability variable consists of ROA, ROE, and profit margin [9]. From each sharia compliance ratio and profitability ratios are averaged and the result is a graph of four quadrants.

One of the bank's performance appraisal tool is CAMELS method, as stated in Bank Indonesia Regulation dated January 24, 2007 [14] regarding Rating System of Commercial Banks Based on Sharia Principles. The Bank's Health Level is the result of qualitative assessment of various aspects affecting the condition or performance of an Islamic commercial bank or Islamic business unit through; quantitative assessment and qualitative assessment of capital factors, asset quality, profitability, liquidity, sensitivity to market risk; and qualitative assessment of management factors. The CAMELS approach in this study do not include sensitivity to market risk factor due to the limited data obtained, especially related to the data of excess capital and the potential loss of exchange rate which become the formula/ratio to calculate the sensitivity factor.

\section{Method}

This research useses descriptive quantitative approach. In this case, the researchers describe the quantitative data that have been obtained. After the statistical process, the data is interpreted. The reason for choosing this research method is because all data is in the form of financial ratios and can be directly and easily explained. The population of this study are all Islamic Commercial Banks registered in Bank Indonesia from 2012-2016 as many as 13 Banks [15]. While the sample for this research consists of four Islamic Foreign Exchange Banks.

\section{Result}

Table 4.1. Islamic Commercial Bank rating based on Sharia Maqashid Index

\begin{tabular}{|l|c|c|c|c|c|}
\hline \multirow{2}{*}{ BANK } & \multicolumn{5}{|c|}{ SHARIA MAQASHID INDEX } \\
\cline { 2 - 6 } & PI of 1st O & PI of 2nd O & PI of 3rd O & SMI & RANKED \\
\hline Bank Syariah Mandiri & 0.00235 & 0.18596 & 0.10431 & 0.29262 & 2 \\
\hline BNI Syariah & 0.00663 & 0.17580 & 0.09888 & 0.28131 & 3 \\
\hline
\end{tabular}




\begin{tabular}{|l|l|l|l|l|l|} 
Bank Muamalat & 0.00391 & 0.21483 & 0.11298 & 0.33172 & 1 \\
\hline Bank Mega Syariah & 0.00071 & 0.15546 & 0.10621 & 0.26237 & 4 \\
\hline
\end{tabular}

Based on Table 4.1 the total calculation of Sharia Maqashid Index of Bank Muamalat was ranked first followed by Bank Syariah Mandiri at the second level, while BNI Syariah and Bank Mega Syariah ranked third and fourth. These results are similar to the results of Prasetyowati, et. al [16] study which reveals that Bank Muamalat is the best performing bank based on Sharia Maqashid Index measurement compared to other Islamic banks.

Table 4.2. Performance of Islamic Commercial Banks based on SCnP

\begin{tabular}{|c|c|c|c|c|c|c|c|c|c|c|c|c|c|c|c|}
\hline \multirow[b]{2}{*}{ BANK } & \multicolumn{3}{|c|}{2012} & \multicolumn{3}{|c|}{2013} & \multicolumn{3}{|c|}{2014} & \multicolumn{3}{|c|}{2015} & \multicolumn{3}{|c|}{2016} \\
\hline & $\begin{array}{l}\mathrm{SC} \\
(\%)\end{array}$ & $\begin{array}{c}\mathrm{P} \\
(\%)\end{array}$ & Q & $\begin{array}{l}\mathrm{SC} \\
(\%)\end{array}$ & $\begin{array}{c}\mathrm{P} \\
(\%)\end{array}$ & Q & $\begin{array}{l}\mathrm{SC} \\
(\%)\end{array}$ & $\begin{array}{c}\mathrm{P} \\
(\%)\end{array}$ & Q & $\begin{array}{l}\text { SC } \\
(\%)\end{array}$ & $\begin{array}{c}\mathrm{P} \\
(\%)\end{array}$ & Q & $\begin{array}{l}\mathrm{SC} \\
(\%)\end{array}$ & $\begin{array}{c}\mathrm{P} \\
(\%)\end{array}$ & Q \\
\hline $\begin{array}{l}\text { Bank } \\
\text { Syariah } \\
\text { Mandiri }\end{array}$ & 74 & 12 & LRQ & 74 & 8 & LRQ & 73 & 2 & LLQ & 75 & 4 & LRQ & 76 & 4 & LRQ \\
\hline $\begin{array}{l}\text { BNI } \\
\text { Syariah }\end{array}$ & 71 & 8 & LLQ & 72 & 8 & LLQ & 72 & 8 & ULQ & 73 & 7 & ULQ & 73 & 7 & ULQ \\
\hline $\begin{array}{l}\text { Bank } \\
\text { Muamalat }\end{array}$ & 81 & 12 & LRQ & 83 & 6 & LRQ & 82 & 2 & LRQ & 83 & 2 & LRQ & 84 & 2 & LRQ \\
\hline $\begin{array}{l}\text { Bank } \\
\text { Mega } \\
\text { Syariah }\end{array}$ & 67 & 25 & ULQ & 67 & 13 & ULQ & 66 & 4 & ULQ & 66 & 4 & LLQ & 67 & 7 & ULQ \\
\hline
\end{tabular}

Table 4.2 shows the performance measurements using the SCnP approach. It indicates that for five years all Islamic Commercial Bank in Indonesia spread in upper left quadrant, lower right quadrant, and lower left quadrant. These results are fairly similar to the finding of Ratnaputri [17] research. This result suggests that there is no Islamic Commercial Bank in Indonesia is located in upper right quadrant, indicating a high sharia compliance while having high profitability.

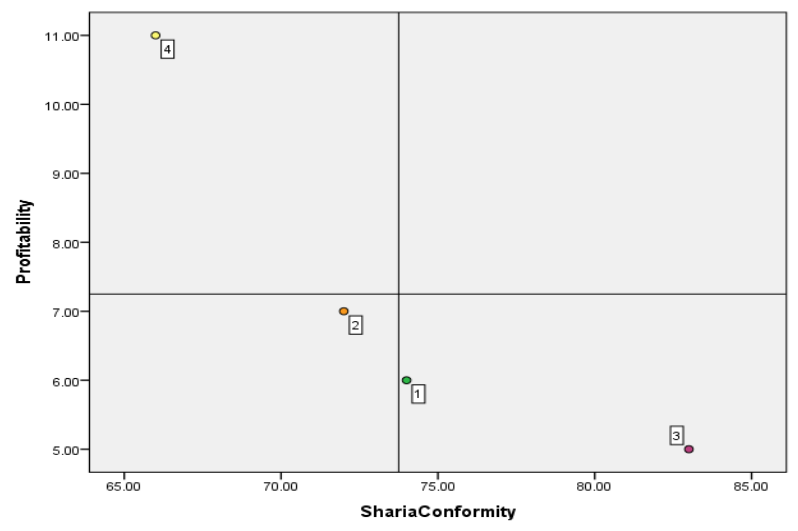

Fig. 4. SCnP Quadrant

In general, Islamic commercial bank performance based on SCnP approach in the period of 2012-2016 is depicted in Figure 4.1

Note:

1. Bank Syariah Mandiri (1) and Bank Muamalat (3) are in lower right quadrant, meaning have a high level of sharia compliance but having low profitability level.

2. BNI Syariah (2) is in lower left quadrant, indicating of a low level of sharia compliance and profitability level. 
3. Bank Mega Syariah (4) is in upper left quadrant, means having a low level of sharia compliance but has a high level of profitability.

Table 4.3 Performance of Islamic Commercial Banks based on CAMELS

\begin{tabular}{|c|c|l|c|l|l|l|l|l|l|l|}
\hline \multicolumn{1}{|c|}{ Years } & \multicolumn{2}{|c|}{2012} & \multicolumn{2}{c|}{2013} & \multicolumn{2}{c|}{2014} & \multicolumn{2}{c|}{2015} & \multicolumn{2}{|c|}{2016} \\
\hline Bank & Result & Predicate & Result & Predicate & Result & Predicate & Result & Predicate & Result & Predicate \\
\hline $\begin{array}{l}\text { Bank } \\
\text { Syariah } \\
\text { Mandiri }\end{array}$ & 76.75 & $\begin{array}{l}\text { Fairly } \\
\text { Healthy }\end{array}$ & 76.81 & $\begin{array}{l}\text { Fairly } \\
\text { Healthy }\end{array}$ & 66.28 & $\begin{array}{l}\text { Fairly } \\
\text { Healthy }\end{array}$ & 70.17 & $\begin{array}{l}\text { Fairly } \\
\text { Healthy }\end{array}$ & 70.47 & $\begin{array}{l}\text { Fairly } \\
\text { Healthy }\end{array}$ \\
\hline $\begin{array}{l}\text { BNI } \\
\text { Syariah }\end{array}$ & 70.62 & $\begin{array}{l}\text { Fairly } \\
\text { Healthy }\end{array}$ & 76.51 & $\begin{array}{l}\text { Fairly } \\
\text { Healthy }\end{array}$ & 75.50 & $\begin{array}{l}\text { Fairly } \\
\text { Healthy }\end{array}$ & 76.60 & $\begin{array}{l}\text { Fairly } \\
\text { Healthy }\end{array}$ & 76.68 & $\begin{array}{l}\text { Fairly } \\
\text { Healthy }\end{array}$ \\
\hline $\begin{array}{l}\text { Bank } \\
\text { Muamalat }\end{array}$ & 76.16 & $\begin{array}{l}\text { Fairly } \\
\text { Healthy }\end{array}$ & 69.49 & $\begin{array}{l}\text { Fairly } \\
\text { Healthy }\end{array}$ & 66.97 & $\begin{array}{l}\text { Fairly } \\
\text { Healthy }\end{array}$ & 67.36 & $\begin{array}{l}\text { Fairly } \\
\text { Healthy }\end{array}$ & 67.27 & $\begin{array}{l}\text { Fairly } \\
\text { Healthy }\end{array}$ \\
\hline $\begin{array}{l}\text { Bank } \\
\text { Mega } \\
\text { Syariah }\end{array}$ & 78.49 & $\begin{array}{l}\text { Fairly } \\
\text { Healthy }\end{array}$ & 77.67 & $\begin{array}{l}\text { Fairly } \\
\text { Healthy }\end{array}$ & 69.02 & $\begin{array}{l}\text { Fairly } \\
\text { Healthy }\end{array}$ & 69.34 & $\begin{array}{l}\text { Fairly } \\
\text { Healthy }\end{array}$ & 76.89 & $\begin{array}{l}\text { Fairly } \\
\text { Healthy }\end{array}$ \\
\hline
\end{tabular}

Table 4.4 Comprehensive Measurement Performance

\begin{tabular}{|l|c|c|l|}
\hline \multicolumn{1}{|c|}{ Bank } & Ranked & Quadrant & Predicate \\
\hline Bank Syariah Mandiri & 2 & LRQ & Fairly Healthy \\
\hline BNI Syariah & 3 & LLQ & Fairly Healthy \\
\hline Bank Muamalat & 1 & LRQ & Fairly Healthy \\
\hline Bank Mega Syariah & 4 & ULQ & Fairly Healthy \\
\hline
\end{tabular}

Table 4.4 shows that two Islamic banks (Bank Syariah Mandiri and Bank Muamalat) which have the highest index maqashid value and have a fairly healthy predicate not necessarily that the banks have a high level of sharia suitability and a high profitability. This finding also shows that there is also an Islamic bank which is in the lowest maqashid index (Bank Mega Syariah) and has a fairly healthy predicate but has a high profitability level (in upper left quadrant).

However, for Islamic banks with first and second ranking with the index maqashid method, the result consistently shows the possibility of being in two quadrants, i.e. in upper right quadrat or low right quadrant. This means that an Islamic bank with a first and second ranking maqashid index does not necessarily have a high level of profitability. Further, the result indicates that every Islamic bank with a first and second ranking maqashid index has a high sharia conformity value.

\section{Conclusion, implication, and future research}

The measurement of Islamic Commercial Banks performance in 2012-2016 using maqashid index method shows the varied results of Islamic Commercial Banks in Indonesia. The best performance was achieved by Bank Muamalat who consistently maintained the performance that was ranked first. Performance measurements using the $\mathrm{SCnP}$ approach indicate that for five years all Islamic Commercial Banks in Indonesia are spread out in upper left quadrant, lower right quadrant, lower left quadrant, and that means no Islamic Commercial Banks in Indonesia in the upper right quadrant which has a high sharia suitability and has a high profitability. The measurement of performance using CAMEL approach shows that for five years all banks has a fairly healthy performance rating. These findings suggest that, to provide a comprehensive picture of their performance, Islamic banks need to adopt both Sharia-based and financial-based 
performance measures concurrently. The inclusion of these approaches will enable the Islamic bank growing fast and building the public confidence. This study bears a drawback related to the sample used, which contains of four banks. Considering the important of this study's finding; thus, it is recommended that this performance measurement assessment need to be tested in other Islamic banks and in other financial institution.

\section{References}

1. P.M. Senge, G. Carstedt, and P.L. Porter, "Innovating Our Way to the Next Industrial Revolution," MIT Sloan Management Review, 42(2), pp. 24-38 (2001)

2. S.V. Scott, J.V. Reenen, and M. Zachariadis, "The Long-Term Effect of Digital Innovation on Bank Performance: An Empirical Study of SWIFT Adoption in Financial Services," Centre for Economic Performance, 992, pp. 1-49 (2017)

3. R.M. Zaman, H. Movassaghi, "Interest-Free Islamic Banking: Ideals and Reality," International Journal of Finance, 14(4), pp. 2428-2442 (2002)

4. M.H. Bedoui, "Sharia-based Ethical Performance Measurement Framework," Chairs for Ethics and Financial Norms, pp. 1-12 (2012)

5. M.O. Mohammed, D.A Razak, "The Performance Measures of Islamic Banking Based on the Maqashid Framework," Paper of IIUM International Accounting Conference (INTAC IV) held at Putra Jaya Marroitt, pp. 1-17 (2008)

6. U. Chapra, Sistem Moneter Islam, Jakarta: Gema Insasi Press \& Tazkia Press (2000)

7. D. Suhartanto, et al., "Loyalty Intention towards Islamic Bank: The Role of Religiosity, Image, and Trust," International Journal of Economics and Management, 12(1), pp. 119-132 (2018)

8. M. Ayub, C. Paldi, "Dichotomy between Syariah Compliance and The Economic Goals of Islamic Financial Institutions," Journal of Islamic Business and Management, 5(2), pp. 69-98 (2015)

9. M. Kuppusamy, A.S. Saleha, A. Samudhram, "Measurement of Islamic Banks Performance Using a Shariah Conformity and Profitablity Model," Review of Islamic Economics, 13(2), pp. 35-48 (2010)

10. M.S. Antonio, Y.D. Sanrego, M. Taufiq, "An Analysis of Islamic Banking Performance: Maqashid Index Implementation in Indonesia and Jordani,". Journal of Islamic Finance, 1(1): p. 012-029 (2012)

11. D. Suhartanto, et al., "The link between tourism involvement and service performance: Evidence from frontline retail employees," Journal of Business Research, 83, pp. 130137 (2018)

12. S. Yuwono, E. Sukarno, M. Ichsan, "Petunjuk Praktis Penyusunan Balanced Scorecard: Menuju Organisasi Yang Berfokus Pada Strategi," Jakarta: Gramedia Pustaka Utama, (2002)

13. Ulum, "Akuntansi Sektor Publik Sebuah Pengantar," Malang: Universitas Muhammadiyah Malang, (2005)

14. B. Indonesia, "Sistem Penilaian Tingkat Kesehatan Bank Umum Berdasarkan Prinsip Syariah", in 9/24/DPbS, (2007)

15. O.J. Keuangan, "Statistik Perbankan Syariah," Jakarta, (2018)

16. L.A. Prasetyowati, L.H. Handoko, "Pengukuran Kinerja Bank Umum Syariah dengan Maqashid Index dan Sharia Conformity and Profitability (SCnP)," Jurnal Akuntansi dan Keuangan Islam, 4(2): pp. 107-130 (2016)

17. W. Ratnaputri, "The Analysis of Islamic Bank Financial Performance by Using CAMEL, Shariah Conformity and Profitability (SCnP)," Jurnal Dinamika Manajemen, 4(2): pp. 220-232, (2013) 